\title{
ACCESS TO CAPITAL AND CAPITAL STRUCTURE OF THE FIRM
}

\author{
Anastasiya Shamshur
}
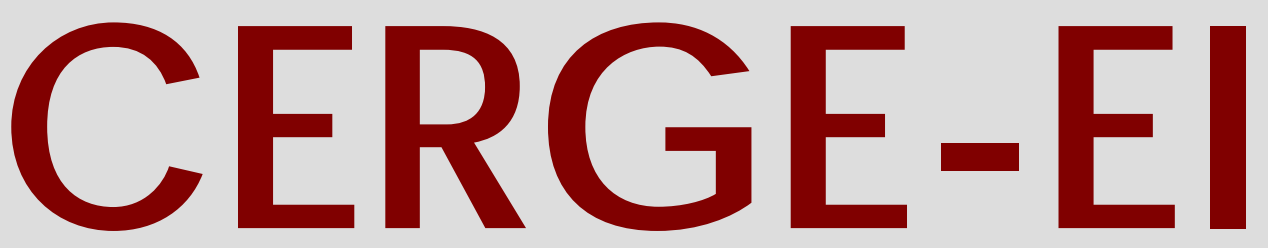

Charles University Centerfor Economic Research and Graduate Education Academy of Sciences of the Czech Republic Ec onomic s Institute 


\title{
Working Paper Series (ISSN 1211-3298)
}

\section{Access to Capital and Capital Structure of the Firm}

Anastasiya Shamshur

\author{
CERGE-EI \\ Prague, October 2010
}
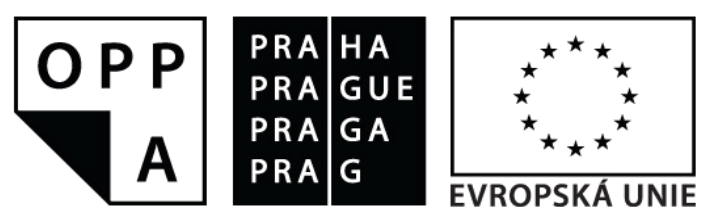

EVROPSKÝ SOCIÁLNÍ FOND

PRAHA \& EU: INVESTUJEME DO VAŠÍ BUDOUCNOSTI 
ISBN 978-80-7343-230-0 (Univerzita Karlova. Centrum pro ekonomický výzkum a doktorské studium)

ISBN 978-80-7344-220-0 (Národohospodářský ústav AV ČR, v.v.i.) 


\title{
Access to Capital and Capital Structure of the Firm*
}

\author{
Anastasiya Shamshur ${ }^{\dagger}$ \\ CERGE-EI ${ }^{\ddagger}$
}

November 2010

\begin{abstract}
The paper examines the importance of financial constraints for firm capital structure decisions in transitions economies during 1996-2006 using endogenous switching regression with unknown sample separation approach. The evidence suggests that differences in financing constraints have a significant effect on a firm's capital structure. Constrained and unconstrained firms differ in capital structure determinants. Specifically, tangibility appears to be an extremely important leverage determinant for constrained firms, while macroeconomic factors (GDP and expected inflation) affect the leverage level of unconstrained firms, suggesting that those firms adjust their capital structure in response to changes in macroeconomic conditions. Moreover, financially unconstrained firms adjust their capital structures faster to the target level, which is consistent with the previous literature.

Abstrakt

Tento clánek zkoumá duležitost financních omezení pro rozhodování firem o jejich kapitálové strukture v prechodových ekonomikách behem let 1996-2006 za použití endogenního prepínacího mechanismu. Dukazy naznacují, že rozdíly ve financních omezeních mají prokazatelný dopad na kapitálovou strukturu firem. Omezené a neomezené firmy se liší v determinantech kapitálové struktury. Konkrétne se toto projevuje jako duležitý pákový determinant pro omezené firmy, zatímco makroekonomické faktory (HDP a ocekávaná inflace) ovlivnují pákovou úroven neomezených firem, což naznacuje, že tyto firmy upravují svou kapitálovou strukturu podle makroekonomických podmínek. Navíc, financne neomezené firmy dosáhnou cílovou hladinu své kapitálové struktury rychleji, což je v souladu s predchozí literaturou.
\end{abstract}

Keywords: Capital Structure, Financing Decisions, Credit Constraints, Eastern Europe

JEL classification: $\mathrm{G} 32, \mathrm{C} 23$

*I would like to thank Jan Hanousek for helpful suggestions and comments. I also benefited from the discussions with Randy Filer and Michael Roberts. Financial support from GACR grant (no. 402/09/1595) is gratefully acknowledged. Part of this paper was written while visiting Organizational Dynamics, School of Arts and Sciences at the University of Pennsylvania and I would like to thank the department for its hospitality. I am thankful to Sarah Peck and Lawrence Smith for English editing. All errors remaining in this text are the responsibility of the author.

${ }^{\dagger}$ Email: anastasiya. shamshur@cerge-ei.cz

${ }^{\ddagger}$ Center for Economic Research and Graduate Education--Economics Institute, a joint workplace of Charles University in Prague and the Academy of Sciences of the Czech Republic. Address: CERGE-EI, P.O. Box 882, Politických vězňů 7, Prague 1, 111 21, Czech Republic

The work was supported by the grant SVV-2010-261 801. 


\section{Introduction}

It is a documented fact that large investment projects are followed by equity and debt issues (Leary and Roberts 2005, Alti 2006). Undertaking a large investment project affects both the hurdle rate and cash flows thus the riskiness of the firm and its valuation are affected as well. Therefore, management is responsible for the identification of a capital structure that results in maximum firm value. Since there is a large body of literature that studies the importance of financial constraints in determining firms' investment behavior and confirms the existence of two distinct regimes, it is reasonable to expect that the resulting capital structure of financially constrained and unconstrained firms is likely determined by different factors.

Capital structure theories offer a number of determinants that are responsible for the variation in capital structure, while the empirical literature strives to find evidence that firms behave in accordance with the theoretical predictions. Scholars have identified a number of proxies that capture cost and benefits of debt financing and estimate leverage of the firm as a function of firm-specific characteristics. ${ }^{1}$ Firm characteristics are found to be important determinants of capital structure, they also determine firm's demand for capital, however, Faulkender and Petersen (2006) point out that supply of capital and firm's ability to access capital markets also affect capital structure.

The problem of access to capital was particularly evident in Central and Eastern European (CEE) economies during the transition. For example, Haas and Peeters (2006), and Nivorozhkin (2005) report that firms in these economies tend to be significantly underlevered suggesting that they have limited access to external financing. It is not surprising since even nowadays debt remains the main source of financing in many transition countries due to underdeveloped capital markets and lack of equity capital. ${ }^{2}$ Moreover, the majority of firms in these economies are

\footnotetext{
${ }^{1}$ This literature is fairly extensive and includes contributions of Rajan and Zingales (1995), Titman and Wessels (1988) and Frank and Goyal (2009).

${ }^{2}$ According to a survey carried out by European Commission in 2006 66\% of surveyed firms go to banks to obtain financing (Figure 1). However, the percentage depends on the region (Figure 2): $85 \%$ of Mediterranean firms go to banks to obtain financing, while in Central Europe this
} 
private, thus, asymmetric information is particularly large for them, while the cost of collecting information about these firms for financial institutions is high.

At the same time, in central planning economies the vast majority of firms initially was state-owned. The period of central planning could be characterized by soft-budget constraints meaning that firms had access to formal or informal state subsidies. Access to financing was not performance-based and sometimes poor performing firms had easier access to external investment funds than the better performing ones (Grosfeld and Roland 1997, Konings, Rizov, and Vandenbussche 2003, Lizal and Svejnar 2002). Then, in 1991 the transformation of economic systems together with privatization had started. These changes led to the evolution of nature of budget constraints: privatized firms were experiencing hard credit constraints and were forced to rely mostly on their internal funds, while state-owned ones still had access to cheap financing.

Despite of the credit constraints hardening process, the literature highlights a number of market imperfections that cause firms to be credit constrained (Stiglitz and Weiss 1981, Hubbard 1998). Specifically, in transition economies this is due to large asymmetric information, which hinders access to external sources of financing (even in cases when firms do not have sufficient internal sources); high transaction costs associated with an application for loans; state monopoly in credit markets; interest rate ceilings imposed by the government (Rizov 2004); low returns on investment; high risk; and underdeveloped financial market. The existence of problems with access to the credit markets is supported by the data. For example, according to the Business Environment and Enterprise Performance Survey (BEEPS) carried out by the European Bank for Reconstruction and Development (EBRD) in 2002, about a half of surveyed enterprises have difficulties with access to financing (Figure 3). These difficulties are well documented in Central European countries (about 50\% of the firms in the Czech Republic, Hungary, Poland and Slovakia consider access to finance as a moderate or a major obstacle for their development) and less severe percentage is about $65 \%$ and in Baltic states it is only $53 \%$. 
in the Baltic region (only $25 \%$ of firms has experienced difficulties with access to finance). The same survey reports that the major obstacle in obtaining financing is its cost (Figure 4). The cost of capital is particularly high in Poland (more than $70 \%$ of respondents think that the capital is too expensive), in the Czech Republic and Slovakia external capital is more affordable for firms (50\% of firms consider the cost of capital as a serious obstacle), while in Baltic States only 30\% of firms suffer from high interest rates and other charges. Another survey that was carried out by the European Commission in 2006 focuses on small and medium enterprises (SME) access to finance in the new EU-10 member states. Again, half of the surveyed firms experience difficulties with access to finance through banks: $44 \%$ of managers feel that access to loans granted by banks is difficult as oppose to $42 \%$ who see it as being easy (Figure 5). Although firms report that nowadays it is easier to obtain a bank loan than a few years ago (Figure 6), the numbers imply that the situation regarding access to external financing has hardly improved even after the countries became EU members. At the same time, the existence of two approximately equally sized groups of firms that differ in their access to capital provides an opportunity to address a number of questions: Do the capital structure decisions of financially constrained firms differ from the capital structure decisions of unconstrained firms? Are their capital structures decisions determined by the same factors? How do financial constraints affect the speed of adjustment to the target capital structure? This paper aims to answer these questions by analyzing the financial behavior of constrained and unconstrained firms in the transition countries during the period 1996-2006.

The paper proceeds as follows. The next section surveys the literature. In section 3 I describe the data sources and provide summary statistics of the sample. Section 4 explains the econometric methods and discusses the determinants of capital structure in two distinct regimes. Section 5 considers the effect of financial constraints presence on speed of adjustment to target capital structure. I summarize the paper and conclude in section 6 . 


\section{Literature}

Traditional capital structure theories assume that capital availability entirely depends on characteristics of the firm. However, according to the credit channel literature, a firm's debt issue patterns depend on its access to financial markets. In theory, a firm is considered to be financially constrained if it does not have sufficient internal sources to undertake investment opportunities and the cost of getting external financing is high. The main problem of the empirical literature is that the obtained results are highly dependent on the methodology used to identify whether a firm experiences credit constraints or not. For example, Fazzari, Hubbard, and Petersen (1988) use the annual Value Line database in 1969-1986, which covers manufacturing firms in the US to identify the presence of financial constraints based on the differential sensitivity of corporate investment to cash flow. The financing constraints are present if the coefficient on cash flow for relatively constrained firms is higher than for relatively unconstrained ones. The authors distinguish between firms based on the dividend payout ratio: the higher the dividend payout ratio, the less constrained the firm. This classification scheme is employed by a large number of studies. For example, Korajczyk and Levy (2003) study the effect of macroeconomic conditions on capital structure and categorize firms by their dividend level similar to Fazzari, Hubbard, and Petersen (1988). In addition, the authors also condition on Tobin's Q to ensure that financially constrained firms are not financially distressed and have investment opportunities.

However, Kaplan and Zingales (1997), Kaplan and Zingales (2000) question the validity of Fazzari, Hubbard, and Petersen's (1988) classification scheme and the interpretation of their empirical results. They offer different classification based on the availability of funds and the demand for them using firms' financial information and annual managers' reports, and show, providing theoretical and empirical arguments, that investment cash flow sensitivities are not good indicators of financing constraints. Kaplan and Zingales's (1997) results are confirmed by Cleary (1999), who finds that firms with higher creditworthiness are extremely sensitive to internal 
funds availability than less creditworthy firms.

Moyen (2004) contributes to this debate by investigating different classification schemes (dividends payout policy, firms' cash flow, investment, Cleary's index). She finds that depending on which identification criterion is applied, cash flow sensitivity of financially constrained firms could be higher or lower than that of financially unconstrained ones.

Alternatively, Vermeulen (2002) and Pal and Ferrando (2006) use balance sheet information and profit and loss accounts. Vermeulen (2002) uses a financial gap ${ }^{3}$ to sort out firms into groups. The firm is defined as credit constrained when its financing gap is positive and the firm is not able to access external financing. Relatively constrained firms are those which despite the positive financing gap can afford expensive external sources. Firms are considered unconstrained if they have either a negative financing gap or are able to attract relatively cheap external financing. However, Schiantarelli (1995) argues that a single indicator is not sufficient to decide whether a firm is credit constrained or not. Pal and Ferrando (2006) take into account this shortcoming of the previous literature and rely on five criteria - total investments, financing gap, financial debt, new shares issuance, and average interest payments on debt relative to interest rates charged in the local credit markets which are related to financing conditions of firms. Usage of several interrelated variables allows for the placement of a firm into the constrained, relatively constrained or unconstrained group utilizing all available information. For example, negative total investment (decrease in fixed assets) signals that a firm has experienced credit constraints since it liquidates fixed assets. A positive financing gap indicates that the firms' total investment is higher than the current cash flow and that the firm needs external financing. If total investments and the financing gap are both positive, firms need external financing. Firms are sorted out into unconstrained and relatively constrained categories based on the price they pay to obtain necessary financing. Those firms, which are able to get financial debt at a lower price than

\footnotetext{
${ }^{3}$ The financial gap is defined as the nominal spending on fixed investment and cash flow.
} 
the country-specific retail interest rates are defined as unconstrained. If the price is higher, a firm falls into the relatively constrained category. Firms which under these conditions are not attracting financing are defined as absolutely constrained. Finally, separate equations are estimated for each group of firms.

All the studies considered above use the exogenous classification of firms. This strategy makes the results highly sensitive to the point of sample separation because it could be problematic to decide which group a firm belongs to since the severity of financial constraints faced by the firm is not directly observable. Recent papers strive to overcome these problems using endogenous sample separation methodology (Hovakimian and Titman 2006, Hobdari, Derek, and Mygind 2009). Hovakimian and Titman (2006) examine the role of financial constraints for firm investments by analyzing the relationship between investment expenditures and proceeds from voluntary asset sales. To avoid a priori sample separation, the authors apply an endogenous switching regression approach with unknown sample separation (Maddala and Nelson 1994, Maddala 1986). The advantage of this approach is that the likelihood of a firm to be financially constrained is endogenously determined by multiple firm characteristics, so that firm is not fixed in one regime over time. Therefore, a firm switches the regime when its propensity of being in the constrained or in the unconstrained regime reaches a certain unobservable threshold value. To estimate the likelihood of a firm being financially constrained, Hovakimian and Titman (2006) use a number of factors, which are firm's size, age, leverage, financial slack, marketto-book ratio, dummy variables for dividend payout and bond rating. However, Hobdari, Derek, and Mygind (2009), who study capital investments and determinants of financial constraints in Estonia in 1993-2002, offer a different composition of the sample separation criteria. They include both financial characteristics of the firm (debt to capital ratio, interest payments to sales ratio and liquid financial assets to capital ratio) and firm-specific factors (ownership concentration, size of the firm and its age). In addition, the authors account for soft budget constraints the firms may face during early transition years. Both Hovakimian and Titman (2006) 
and Hobdari, Derek, and Mygind's (2009) papers confirm the existence of two distinct regimes (constrained and unconstrained), which determine firms' investment behavior.

It is necessary to stress that the literature on credit constraints is mostly focused on the relation between financing availability and investments. The effect of credit constraints on the firms' capital structure choice has not been studied. ${ }^{4}$ This paper contributes to the academic literature in the following ways. First, the paper studies how the financial constraints affect capital structure of the firm and its determinants using the endogenous sample separation approach. Leverage of constrained firms appeared to be more dependent on such determinants as size of the firm, its tangibility and industry median leverage, while leverage of unconstrained firms is responsive to macroeconomic factors, because they are able to adjust their capital structures in accordance with economic changes. Second, the paper documents systematic differences in the speed of adjustment to target leverage between financially constrained and unconstrained firms. Constrained firms adjust their leverage to the optimal level faster than unconstrained ones. This finding might seem counterintuitive, however, firms change their capital structures only when they are sufficiently far away from the target. Since unconstrained firms have more financial freedom they do not drift away from their targets, while constrained firms usually underlevered and adjust to their targets when they have an opportunity to do so.

\section{Data}

I consider non-financial firms over the 1996-2006 period with data available from Amadeus database constructed by Bureau Van Dijk. In this study I use the Top 250,000 companies module of this database and focus on seven Eastern European countries, which are the Czech Republic, Estonia, Hungary, Latvia, Lithuania,

\footnotetext{
${ }^{4}$ To my knowledge there is only one paper by Korajczyk and Levy (2003), which studies how macroeconomic conditions affect capital structure choice. The authors conduct their analysis separately for financially constrained and unconstrained firms and find that unconstrained firms, in contrast to constrained, time their issue choice when macroeconomic conditions are favorable.
} 
Poland and Slovakia.

I require that all the key variables have no missing data. In addition, I exclude observations if: a) capital is negative; b) leverage does not fall into the interval from one to zero; and c) the trade credit is greater than the sum of current and noncurrent liabilities. ${ }^{5}$ The resulting sample is unbalanced and consists of 51621 observations over the period 1996-2006.

Table 1 presents detailed summary statistics for all firms in the sample. The definitions of all variables are given in the Appendix. It can be seen from the table that the mean of total assets of firms in the sample increases over the years from 33.9 to 54.5 million dollars. However, median total assets are much lower compared to their mean value implying that total assets of only a few firms are large. Tangibility of firms in the sample decreases over time, while profitability stays approximately the same. Interestingly, mean firms' leverage decreases with years suggesting lower usage of debt in financing firms' activities.

Table 2 summarizes relevant variables by countries. According to the table, the Czech Republic and Poland have the greatest coverage, while Lithuania has the lowest coverage. At the same time, in terms of total assets, the largest companies are located in Poland and Slovak Republic, but Lithuania again has the lowest mean total assets. Polish firms have the highest tangibility, while Estonian and Latvian firms enjoy highest returns on assets. Firms in Hungary have the greatest growth opportunities and highest leverage. The average age of firms in the sample is about 10 years.

\footnotetext{
${ }^{5}$ In this case, according to the leverage definition, the numerator will be negative. For more details see Appendix.
} 


\section{Switching Regression Model}

The standard empirical specification of the model can be summarized as follows

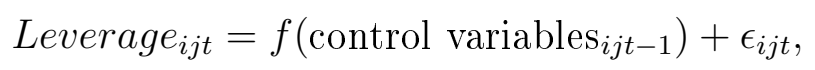

where $i$ stands for the firm, $j$ stands for the country and $t$ refers to the time period. Leverage is defined as debt over debt plus equity, where debt is equal to total liabilities minus trade credit. ${ }^{6}$ Control variables contain the size of the firm proxied by logarithm of total assets, tangibility defined as tangible assets over total assets, profitability is profit over total assets, growth opportunities are proxied by GDP, expected inflation, maturity of assets defined as current assets to total assets, age of the firm and median industry leverage.

However, the model itself does not take into account that a firm could be heavily dependent on external finance availability or, in other words, could be financially constrained. As has been discussed above, most prior studies start with dividing firms into groups (constrained and unconstrained) and then estimate parameters of interest separately for each subsample. However, Moyen (2004) demonstrates that a prior assignment of a firm into a particular group is quite subjective and the results depend on the separation criterion applied. Alternatively, application of the switching regression model with unknown sample separation allows for the allocation of the observational units to a specific regime depending on the value of the latent decision variable relative to the threshold value (Maddala and Nelson 1994). The method was used by Hu and Schiantarelli (1998), Hovakimian and Titman (2006), Almeida and Campello (2007), Hobdari, Derek, and Mygind (2009) to estimate investment-cash flow sensitivities without a priori classifying firms as constrained and unconstrained.

I assume that a firm could either work in a constrained or unconstrained regime, but the points of structural change are not observable and will be estimated together

\footnotetext{
${ }^{6}$ In this case, according to the leverage definition, the numerator will be negative. For more details see Appendix.
} 
with the leverage equation for each regime. Thus, the model is composed of the system of three equations estimated simultaneously:

$$
\begin{array}{r}
Y_{1 i j t}=\beta_{1} X_{i j t}+\epsilon_{1 i j t}, \\
Y_{2 i j t}=\beta_{2} X_{i j t}+\epsilon_{2 i j t}, \\
y_{i j t}^{*}=\delta Z_{i j t}+u_{i j t},
\end{array}
$$

where $Y_{i j t}$ is leverage of firm $i$ in country $j$ at time $t, X_{i j t}$ are leverage determinants, and $\epsilon$ is a random error term. The first two equations in the system of equations (2) are leverage regressions for constrained and unconstrained regimes, and selection equation $y_{i j t}^{*}=\delta Z_{i j t}+u_{i j t}$ estimates the likelihood of the firm operating in either one regime or the other. $Z_{i j t}$ contains the determinants of a firm's propensity of being in either regime at time $t$. The change of the regime occurs when $y_{i j t}^{*}$ reaches a certain unobservable threshold value, so that the status of the firm may change over time.

The selection rule is defined as

$$
\begin{aligned}
& Y_{i j t}=Y_{1 i j t}, \text { iff } y_{i j t}^{*}<0, \\
& Y_{i j t}=Y_{2 i j t}, \text { iff } y_{i j t}^{*} \geq 0 .
\end{aligned}
$$

The parameters $\beta_{1}, \beta_{2}$ and $\delta$ will be estimated using maximum likelihood. It is necessary to assume that $\epsilon_{1 i j t}, \epsilon_{2 i j t}$ and $u_{i j t}$ are jointly normally distributed with zero mean and covariance matrix $\Sigma$.

$$
\Sigma=\left(\begin{array}{ccc}
\sigma_{1}^{2} & \sigma_{12} & \sigma_{1 u} \\
\sigma_{21} & \sigma_{2}^{2} & \sigma_{2 u} \\
\sigma_{u 1} & \sigma_{u 2} & \sigma_{u}^{2}
\end{array}\right)
$$

where $\sigma_{u}^{2}$ is normalized to 1 , because from the switching regression it is only possible to estimate $\delta / \sigma_{u}$, but not $\delta$ and $\sigma_{u}$ separately. I also assume that off-diagonal terms (the covariances) are not equal to zero, although $\sigma_{12}$ is not estimable since it does not appear in the likelihood function (equation (8)). Still the non-zero covariance 
assumption is needed to allow the shocks of leverage to be correlated with the shocks to a firm's characteristics. This assumption is particularly important because $Y_{1 i j t}$ and $Y_{2 i j t}$ are included in $y_{i j t}^{*}$ regressors meaning that they affect the classification of observations in the regimes. As $\sigma_{1 u}$ and $\sigma_{2 u}$ are different from zero, the switch is endogenous, thus, the endogenous switching model with unknown sample separation should be applied.

As the regime the firm is not directly observable, I calculate the probabilities of the firm to be constrained or unconstrained:

$$
\begin{aligned}
& \operatorname{Prob}\left(Y_{i j t}=Y_{1 i j t}\right)=\operatorname{Prob}\left(\delta Z_{i j t}+u_{i j t}<0\right)=\operatorname{Prob}\left(u_{i j t}<-\delta Z_{i j t}\right)=\Phi\left(-\delta Z_{i j t}\right), \\
& \operatorname{Prob}\left(Y_{i j t}=Y_{2 i j t}\right)=\operatorname{Prob}\left(\delta Z_{i j t}+u_{i j t} \geq 0\right)=\operatorname{Prob}\left(u_{i j t} \geq-\delta Z_{i j t}\right)=1-\Phi\left(-\delta Z_{i j t}\right) .
\end{aligned}
$$

Then the likelihood density function for each observation $Y_{i j t}$ is given by

$$
l_{i j t}=\Phi\left(-\delta Z_{i j t}\right) \phi\left(\epsilon_{1 i j t} \mid u_{i j t}<-\delta Z_{i j t}\right)+\left[1-\Phi\left(-\delta Z_{i j t}\right)\right] \phi\left(\epsilon_{2 i j t} \mid u_{i j t \geq-\delta Z_{i j t}}\right) .
$$

And the log-likelihood function for all the observations subject to maximization is given by

$$
\begin{aligned}
\ln L=\sum_{i=1}^{N} \sum_{j=1}^{M} \sum_{t=1}^{T} \ln \{\Phi( & \left.\frac{-\delta Z_{i j t}-\frac{\sigma_{1 u}}{\sigma_{1}^{2}} \epsilon_{1 i j t}}{\sqrt{1-\frac{\sigma_{1 u}^{2}}{\sigma_{1}^{2}}}}\right) \phi\left(\epsilon_{1 i j t}, \sigma_{1}\right)+ \\
+ & {\left.\left[1-\Phi\left(\frac{-\delta Z_{i j t}-\frac{\sigma_{2 u}}{\sigma_{2}^{2}} \epsilon_{2 i j t}}{\sqrt{1-\frac{\sigma_{2 u}^{2}}{\sigma_{2}^{2}}}}\right)\right] \phi\left(\epsilon_{2 i j t}, \sigma_{2}\right)\right\}, }
\end{aligned}
$$

where $\phi(\cdot)$ is the normal density distribution and $\Phi(\cdot)$ is normal cumulative distribution functions.

I start with firm-specific factors which could be associated with the presence of financial constraints. The switching regression approach allows the use of multiple variables to predict whether a firm is constrained or unconstrained. ${ }^{7}$ Following the

\footnotetext{
${ }^{7}$ The literature on financing conditions demonstrates that the obtained results depend on the a-priori criteria used to assign a firm to a particular category (Schiantarelli 1995). Using the
} 
existing investment literature I use the sets of variables including those used by Hovakimian and Titman (2006), Almeida and Campello (2007), and Hobdari, Derek, and Mygind (2009), to identify financial constraints in the context of transition economies. Table 3 briefly summarizes the determinants I find to be relevant for firms operating in transition economies and their expected signs. All these variables are included into the selection equation in lagged form. The next step is the estimation of the endogenous switching regression model with unknown sample separation. The model is estimated by maximum likelihood. As recent research revealed the necessity to control for firm-specific fixed effects (Lemmon, Roberts, and Zender 2008), the leverage regressions are estimated in first differences. I also include year dummies to control for fixed-year effects. The model is estimated over the 1996-2006 period.

Table 4 presents the regression results. Panel A demonstrates that the firms' capital structure decisions are different in the two regimes. These differences are particularly well pronounced for size, profitability and tangibility of the firm and also for the effect of industry median leverage. In both regimes size of the firm and industry median leverage are positively related to leverage. However, the change in size of the firm generates a greater increase in leverage of unconstrained firms. Industry median leverage has significantly higher impact on the leverage of constrained firms. The possible explanation of this fact is that constrained firms have only a few opportunities to borrow, thus, they are striving to adjust their leverage to the median industry leverage, while unconstrained firms may focus on their own target level rather than the common benchmark. Note that the age of the firm is a highly significant determinant of capital structure of the firm. It is negatively related to the leverage of constrained and unconstrained firms indicating that old firms prefer to finance their activities themselves. Profitability also has a highly significant negative effect on the leverage. Under large information asymmetries between firms and financial institutions, banks may use high interest rates to protect themselves, multiple indicators helps to assess the existence of credit constraints more carefully. 
though profitable firms will choose to use their internal sources and demand less credit, while less profitable firms still have to borrow, since they lack internal alternatives. This negative relation is consistent with the pecking order theory and supported by previous findings for small firms (Pendado and de la Rodrigues Torre 2006, Heyman, Deloof, and Ooghe 2008) and for transition economies (Haas and Peeters 2006, Delcoure 2007, Shamshur 2009).

Change in maturity of assets appears to have a different impact on constrained and unconstrained firms. It has positive impact on leverage of constrained firms, while leverage of unconstrained firms and maturity of assets have negative relations. According to Hol and der Wijst (2008), this could be interpreted as evidence of short-term debt usage by constrained firms and long-term debt usage by unconstrained firms. As long-term debt entails higher information costs than short-term debt because stronger proof of creditworthiness is needed, only the unconstrained firms could obtain it.

As expected, tangibility is significant only for a subsample of constrained firms: higher tangibility is associated with higher leverage. This finding is quite intuitive because financial institutions consider tangible assets as collateral. Moreover, such macro factors as GDP and expected inflation significantly affect leverage of unconstrained firms indicating that these firms are able to adjust their leverage in response to economic changes. All firm-specific estimates are significantly different between the two regimes.

The estimates of the selection equation are reported in Panel B. All the characteristics except long-run leverage and firm status (public/private) play an important role in determining the likelihood of the firm belonging to a particular regime. Constrained firms tend to be smaller and younger, have less tangible assets and lower leverage levels. They also have higher growth opportunities and lower levels of financial slack. Lower short-run leverage levels indicate that these firms are not able to borrow as much as necessary even if they face higher growth opportunities. Unexpectedly, soft budget constraints are positively correlated with probability of 
a firm being financially constrained. The obtained result could be connected to the fact that the financing firms receive from government ${ }^{8}$ is mostly used for survival rather than investment, restructuring or optimising capital structure (Grosfeld and Roland 1997, Konings, Rizov, and Vandenbussche 2003, Lizal and Svejnar 2002). Moreover, during the transition period new EU member countries had tightened their policies with respect to government subsidies. Moreover, in line with Hobdari, Derek, and Mygind (2009), it can be concluded that the governmental subsidies are used inefficiently.

The obtained results seem to support the idea of the existence of two different regimes. In order to formally test this preposition I estimate a pooled OLS model which could be considered as the constrained model in the sense that coefficients of two leverage regressions for two different regimes are equal. The results are summarized in Table 5 and Figure 7. In most cases the estimates of the pooled OLS model are between constrained and unconstrained regimes coefficients. In general, the pooled OLS estimates are closer to the constrained firms' estimates from the switching regression. Furthermore, I use a likelihood ratio test with likelihood values for the switching model and OLS. Under the restriction that coefficients of the two leverage equations for two different regimes are equal, the parameters of the selection equation in the switching model are not identified, which complicates the calculation of the degrees of freedom. I follow the suggestions of Goldfeld and Quandt (1976) and use $\chi^{2}$ distribution to conduct a likelihood ratio test by defining the degrees of freedom as the sum of the number of constraints and the number of unidentified parameters. There are 38 degrees of freedom in my model. The critical value of $\chi^{2}$ distribution at $1 \%$ level with 38 degrees of freedom is 61.16 and the value of the likelihood ratio test is 9656.9 . Thus, I conclude that the data are better characterized by two different regimes (constrained and unconstrained) than by one regime.

To test the robustness of the results I estimate the separate leverage regressions

\footnotetext{
${ }^{8}$ Direct government subsidies without expectation of future repayment, tax reductions, trade credits and cheap bank credits.
} 
using a priori classification of the sample into subsamples of constrained and unconstrained firms. Estimations are performed separately for each regime.

A. In every year over the 1996-2006 period firms are sorted into subsamples based on growth opportunities they face and financial slack they have: firms that face high (low) growth opportunities and keep low (high) amount of cash are classified as financially constrained (unconstrained).

B. In every year over the 1996-2006 period firms are ranked based on their tangibility and profitability. Firms which are in the bottom (top) three deciles of tangibility and profitability distributions are assigned to the financially constrained (unconstrained) group.

The results from these estimations are reported in Table 6. In general, they are similar, but substantially weaker. The potential problem with artificial sample separation is that assignment of a firm into a particular group is based on one or two variables, while many factors affect the ability of the firm to attract external financing.

\section{Do constrained and unconstrained firms adjust their capital structures differently?}

In this section I attempt to analyse the differences in the adjustment speed between constrained and unconstrained firms. As I have shown the determinants of capital structure differ across firms with respect to their access to external finance. When the switching model is estimated, the obtained results can be used to calculate the probabilities of the firm to be in either the constrained or unconstrained regime. These probabilities help to assign firms in either one group or the other and then estimate the dynamic capital structure model for each group separately.

I employ a partial adjustment model with firm fixed effects as suggested by Flannery and Rangan (2006). The authors demonstrate that this type of model fits the data 
very well.

First, the target leverage of the firm must be estimated.

$$
Y_{i j t}^{*}=\beta X_{i j t-1}+\nu_{i}
$$

where $Y_{i j t}^{*}$ is a target or optimal leverage of the firm, vector $X_{i j t-1}$ contains one-year lagged leverage determinants found to be important in transition economies. Specifically, I include size of the firm, its age, maturity of assets, tangibility, profitability, GDP, expected inflation and industry median leverage. ${ }^{9}$ Firms' fixed effects $\left(\nu_{i}\right)$ are included into the regression to capture the unobserved firms' heterogeneity documented by Lemmon, Roberts, and Zender (2008) for the US and Shamshur (2009) for Central and Eastern European economies.

Second, to capture dynamic adjustments in leverage ratios, the partial adjustment model will be estimated (Hovakimian, Opler, and Titman 2001, Flannery and Rangan 2006).

$$
Y_{i j t}-Y_{i j t-1}=\lambda\left(Y_{i j t}^{*}-Y_{i j t-1}\right)+\epsilon_{i j t}
$$

where $Y_{i j t}-Y_{i j t-1}$ is an actual change in firm's leverage, $Y_{i j t}^{*}-Y_{i j t-1}$ is the distance between firm's leverage and its target leverage, and $\lambda$ captures the speed of adjustment to the target leverage ratio.

Combining (9) and (10) I get

$$
Y_{i j t}=(\lambda \beta) X_{i j t}+(1-\lambda) Y_{i j t-1}+\lambda \nu_{i}+\epsilon_{i j t}
$$

When estimating equation (11) several econometric problems might be faced. First, firm fixed effect should be taken into account because time-invariant firm characteristics are more likely correlated with the explanatory variables. Ignoring the unobserved firm heterogeneity may cause the estimates to be biased and inconsistent (Wooldridge 2002). Second, the presence of lagged dependent variable in the

\footnotetext{
${ }^{9}$ For the detailed discussion concerning leverage determinants and their expected relationship with target leverage see Haas and Peeters (2006), Shamshur (2009).
} 
regression equation makes the inclusion of firm fixed effect into the model problematic. If first-differencing is applied, the firm-, industry- and country-specific effects are removed, because they do not vary over time, however, this kind of transformation creates a correlation between the transformed lagged dependent variable and the error term. The degree of inconsistency from using the fixed effect when the strict exogeneity assumption fails is of order $T^{-1}$ (Wooldridge 2002). In panels with large time dimension the correlation of the error term with the lagged dependent variable will be insignificant (Roodman 2006), however, my dataset has a short time dimension and a large firm dimension, thus, bias will be substantial (Wooldridge (2002), Baltagi (2005)).

The short panel bias could be addressed in a number of ways. The most common way to deal with the problem is to instrument the lagged dependent variable with an appropriate instrumental variable (IV). This approach is employed by Flannery and Rangan (2006) to estimate the speed of adjustment to the target leverage. The authors use a lagged book debt ratio to instrument the lagged dependent variable which is the market debt ratio. Unfortunately, this instrument is not applicable in my case because the majority of firms in my panel is private and market leverage ratio cannot be calculated for them.

Another way to address the short panel bias problem is to apply the Arellano-Bond estimator which has been designed for small-t large-n panels (Wooldridge 2002). This Generalized Method of Moments (GMM) estimator uses lag levels to instrument for the first differences of endogenous variables, but Blundell and Bond (1998) emphasize that with highly persistent data first-differenced IV or GMM estimators may suffer of the small sample bias due to weak instruments. Blundell and Bond system GMM estimator is designed for persistent panel data and in addition to the lagged level observations uses lagged first differenced observations as instruments for the levels variables. One set of instruments deals with endogeneity of explanatory variables and another set with the correlation between lagged dependent variable and the error term. At the same time, according to Baltagi (2005), the GMM coef- 
ficient estimates are only consistent in the absence of second order serial correlation in the differenced residuals. Given that there is no second order serial correlation in my data, I estimate equation (11) in first differences using GMM and use the levels of all independent variables at the second lag as instruments.

The dynamic panel estimation results are reported in Table 7. The estimated speed of adjustment is different for constrained and unconstrained firms, 17\% (1-0.83) and $56 \%$ (1-0.44) respectively. As expected, unconstrained firms adjust substantially faster towards their targets. This finding is consistent with Leary and Roberts (2005) who argue that firms tend to make adjustments of their capital structure relatively infrequently since adjustment is not costless for them. The adjustment will be less costly for unconstrained firms, since they are able to borrow relatively easy and at lower rates. The idea is also supported by the finding discussed above concerning the higher sensitivity of unconstrained firms' leverage to macroeconomic variables (GDP growth and inflation).

\section{Conclusion}

The paper analyses capital structure determinants of financially constrained and unconstrained firms for a panel of Central and Eastern European firms during 1996-2006 using the endogenous switching regression model with unknown sample separation. The major advantage of this approach is that it allows me to avoid misspecification because the sample separation is determined endogenously based on the set of variables, rather than a single classification criterion. The findings provide strong evidence that differences in financing constraints have a significant effect on firms' capital structure. First, the existence of two separate regimes is confirmed: financially constrained and unconstrained firms differ in the capital structure determinants. Specifically, tangibility appears to be a very important leverage determinant for financially constrained firms as well as size of the firm and industry medial leverage, while macroeconomic factors (GDP and expected inflation) affect 
the leverage level of unconstrained firms suggesting that those firms change their capital structure in response to changes in macroeconomic conditions.

Second, the endogenous switching approach allows me to calculate probabilities of firms being financially constrained. Using calculated probabilities I separate firms to financially constrained and unconstrained to study how the financial constraints affect the speed of adjustment to the target capital structure. The paper documents systematic differences in the speed of adjustment to target leverage between financially constrained and unconstrained firms. Unconstrained firms adjust their leverage to the optimal level faster than constrained ones. Future research should probably consider the determinants of the adjustment speed for these two groups of firms.

Hence, given the documented differences in capital structure determinants and adjustment speed to target leverage of constrained and unconstrained firms, it can be concluded that access to financial markets affects capital structure decisions of firms, although further investigation of adjustment speed determinants for both groups of firms is needed. 


\section{References}

Almeida, H., and M. Campello. 2007. "Financial Constraints, Asset Tangibility, and Corporate Investment." Review of Financial Studies 20:1429-1460.

Alti, A. 2006. "How persistent is the impact of market timing on capital structure?" Journal of Finance 61:1681-1710.

Baltagi, B. 2005. Econometric Analysis of Panel Data. John Wiley and Sons.

Blundell, R., and S. Bond. 1998. "Initial conditions and moment restrictions in dynamic panel data models." Journal of Econometrics 87:115-143.

Brav, O. 2009. "Access to Capital, Capital Structure, and the Funding of the Firm." The Journal of Finance 64 (1): 263-308.

Cleary, S. 1999. "The relationship between firm investment and financial status." The Journal of Finance 54 (2): 673-692.

Delcoure, N. 2007. "The determinants of capital structure in transitional economies." International Review of Economics and Finance 16:400-415.

Faulkender, M., and M. A. Petersen. 2006. "Does the Source of Capital Affect Capital Structure?" The Review of Financial Studies 19 (1): 45-79.

Fazzari, Hubbard, and Petersen. 1988. "Financing Constraints and Corporate Investment." Brookings Papers on Economic Activity, pp. 141 - 206.

Flannery, M., and Rangan. 2006. "Partial adjustment toward target capital structures." Journal of Financial Economics 79 (3): 469-506.

Frank, M. Z., and V. K. Goyal. 2009. "Capital Structure Decisions: Which Factors are Reliably Important?" Financial Management 38 (1): 1-37.

Goldfeld, S., and R. Quandt. 1976. Chapter Techniques for Estimating Switching Regressions of Studies in Non-linear Estimation, edited by S. Goldfeld and R. Quandt, 3-36. Cambridge: Ballinger.

Grosfeld, I., and G. Roland. 1997. "Defensive and strategic restructuring in central 
European enterprises." Journal of Transforming Economies and Societies 3 (4): $21-46$.

Haas, R., and M. Peeters. 2006. "The dynamic adjustment towards target capital structure of firms in transition economies." Economics of Transition 14 (1): $133-169$.

Heyman, D., M. Deloof, and H. Ooghe. 2008. "The Financial Structure of Private Held Belgian Firms." Small Business Economics 30:301-313.

Hobdari, B., C. J. Derek, and N. Mygind. 2009. "Capital investment and determinants of financial constraints in Estonia." Economic Systems 33 (4): 344-359.

Hol, S., and N. Van der Wijst. 2008. "The Financial Structure of Nonlisted Firms." Applied Financial Economics 18:559-568.

Hovakimian, A., T. Opler, and S. Titman. 2001. "Debt-equity choice." Journal of Financial and Quantitative Analysis 36 (1): 1-24.

Hovakimian, G., and S. Titman. 2006. "Corporate Investment with Financial Constraints: Sensitivity of Investment to Funds from Voluntary Asset Sales." Journal of Money, Credit, and Banking 38 (2): 357-374.

Hu, X., and F. Schiantarelli. 1998. "Investment and Capital Market Imperfections: A Switching Regression Approach Using U.S. Firm Panel Data." Review of Economics and Statistics 80 (3): 466-479.

Hubbard, R. 1998. "Capital-Market Imperfections and Investment." Journal of Economic Literature 36 (1): 193-225.

Jensen, M.C., and W. Meckling. 1976. "Theory of the firm: managerial behavior, agency costs and ownership structure." Journal of Financial Economics 3, no. 305-360.

Kaplan, S., and L. Zingales. 1997. "Do investment-cash flow sensitivities provide useful measures of financing constraints?" Quarterly Journal of Economics 112:169-215. 
_ 2000. "Investment-cash flow sensitivities are not valid measures of financing constraints." Quarterly Journal of Economics 115:705-712.

Kashyap, A., O. Lamont, and J. Stein. 1994. "Credit conditions and the cyclical behavior of inventories." Quarterly Journal of Economics 109:565 - 592.

Konings, J., M. Rizov, and H. Vandenbussche. 2003. "Investment and financial constraints in transition economies: micro evidence from Poland, the Czech Republic, Bulgaria and Romania." Economics Letters 78 (2): 253-258.

Korajczyk, R. A., and A. Levy. 2003. "Capital structure choice: macroeconomic conditions and financial constraints." Journal of Financial Economics 68:75109.

Leary, M., and M. Roberts. 2005. "Do Firms Rebalance Their Capital Structures?" Journal of Finance 60:2575-2619.

Lemmon, M. L., M. R. Roberts, and J. F. Zender. 2008. "Back to the beginning: Persistence and the cross-section of corporate capital structure." Journal of Finance 63 (4): 1575-1608.

Lizal, L., and J. Svejnar. 2002. "Investment, Credit Rationing, and the Soft Budget Constraint: Evidence from Czech Panel Data." Review of Economics and Statistics 84 (2): 353-370.

Maddala, G. S. 1986. Chapter Disequilibrium, Self-Selection, and Switching Models of Handbook of Econometrics, edited by Z. Griliches and M.D. Intriligator, Volume 3, 1633-1688. Amsterdam: Elsevier Science.

Maddala, G. S., and F. Nelson. 1994. Chapter Switching regression models with exogenous and endogenous switching of Econometric Methods and Applications, edited by G. Maddala, Volume 2 of Economists of the Twentieth Century, 369372. Aldershot.

Moyen, N. 2004. "Investment-Cash Flow Sensitivities: Constrained versus Unconstrained Firms." Journal of Finance 59 (5): 2061-2092. 
Myers, S. C. 1977. "Determinants of corporate borrowing." Journal of Financial Economics 5:147-175.

Myers, S. C., and N. Majluf. 1984. "Corporate financing and investment decisions when firms have information that investors do not have." Journal of Financial Economics 13:187-224.

Nivorozhkin, E. 2005. "Financing Choices of Firms in EU Accession Countries." Emerging Markets Review 6:138-169.

Oliner, S., and G. Rudebusch. 1992. "Sources of the Financing Hierarchy for Business Investment." Review of Economics and Statistics 74 (4): 643-654.

Pal, R., and A. Ferrando. 2006. "Financing Constraints and firms' cash policy in the Euro Area." ECB Working Paper, no. 642.

Pendado, J., and L.C. de la Rodrigues Torre. 2006. "How Does Financial Distress Affect Small Firms' Financial Structure?" Small Business Economics 26:377391.

Rajan, R., and L. Zingales. 1995. "What do we know about capital structure? Some evidence from international data." Journal of Finance 50:1421-1460.

Rizov, M. 2004. "Credit Constraints and Profitability: Evidence from a Transition Economy." Emerging Markets Finance and Trade 40 (4): 63-83.

Roodman, D. 2006. "How to do Xtabond2: An Introduction to Difference and System GMM in Stata." Center for Global Development Working Paper, vol. No. 103.

Schiantarelli, F. 1995. "Financial Constraints and Investment: A Critical Review of Methodological Issues and International Evidence." Oxford Review of Economic Policy 12:70-89.

Shamshur, A. 2009. "Is the Stability of Leverage Ratios Determined by the Stability of the Economy?" CERGE-EI Working Paper Series, no. 393. 
Stiglitz, J., and A. Weiss. 1981. "Credit Rationing in Markets with Imperfect Information." American Economic Review 71 (3): 393-410.

Titman, S., and R. Wessels. 1988. "The determinants of capital structure choice." Journal of Finance 43:1-21.

Vermeulen, P. 2002. "Investment and Financing Constraints: What does the data tell?" EIFC Working Paper, no. 25.

Wooldridge, J. 2002. Econometric Analysis of Cross Sectional and Panel Data. The MIT Press, Cambridge. 


\section{Appendix}

Leverage $=\frac{\text { debt }}{\text { debt+equity }}$, where debt=total liabilities-trade credit (Haas and Peeters 2006).

Short-run leverage $=$ short-term debt/total assets.

Long-run leverage $=$ long-term debt/total assets.

Age $=\log \left(\right.$ Year $_{t}-$ year of incorporation $)$.

Log(total assets) is the natural log of total assets.

Tangibility=tangible assets/total assets.

Profitability $=$ profit $/$ total assets

Maturity of assets $=$ current assets/total assets

Growth opportunities is the percentage change in total assets from the previous to the current year.

Median industry leverage is measured as the median leverage of the group defined by the industry code (NACE double digit) and by year.

Financial slack $=$ cash $/$ total asset $_{t-1}$

Quoted $=1$ if the firm is listed and $=0$ if the firm is private. 


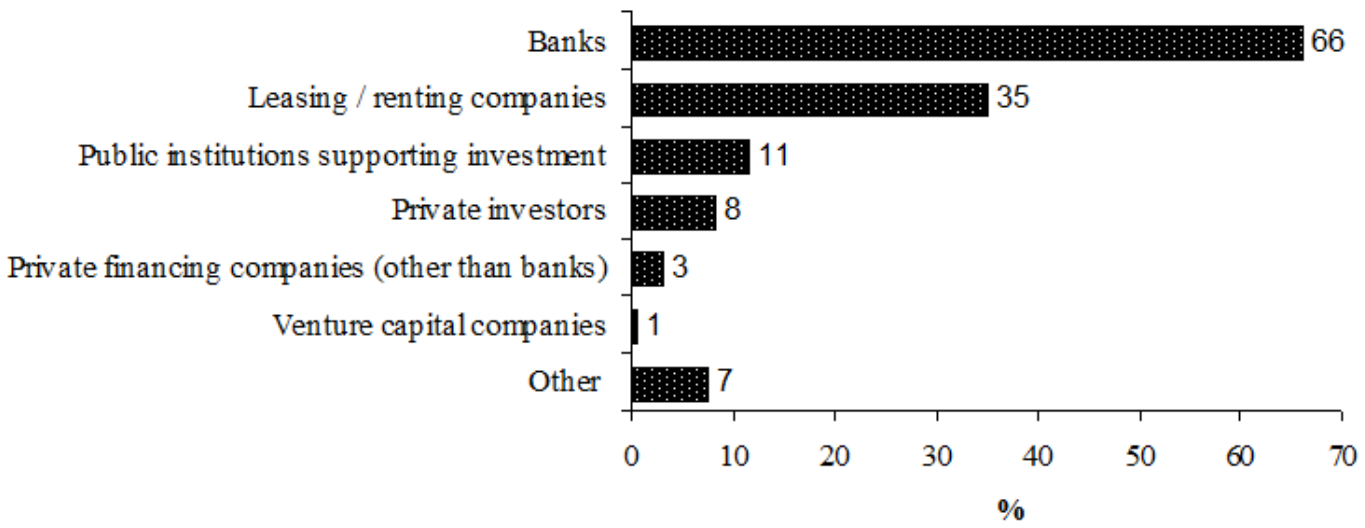

Figure 1: Institutions firms go to for financing

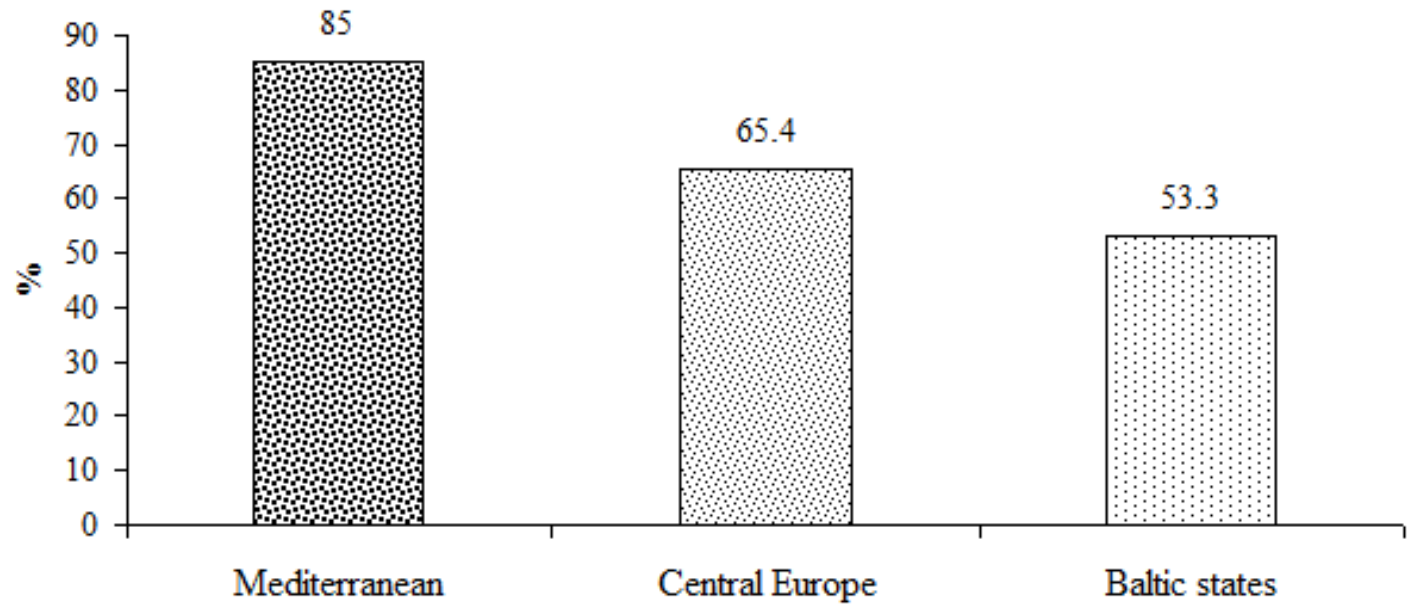

Figure 2: $\%$ of firms in new EU-10 countries that go to banks to obtain financing by regions

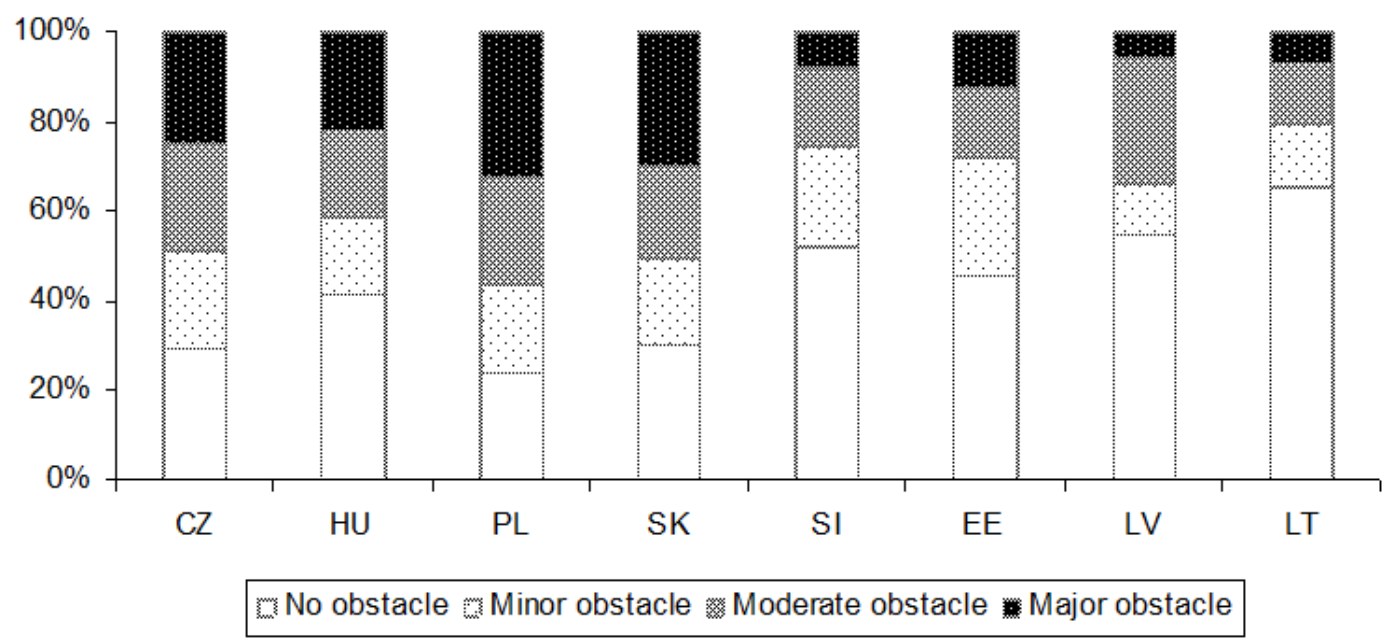

Figure 3: Access to financing by countries 


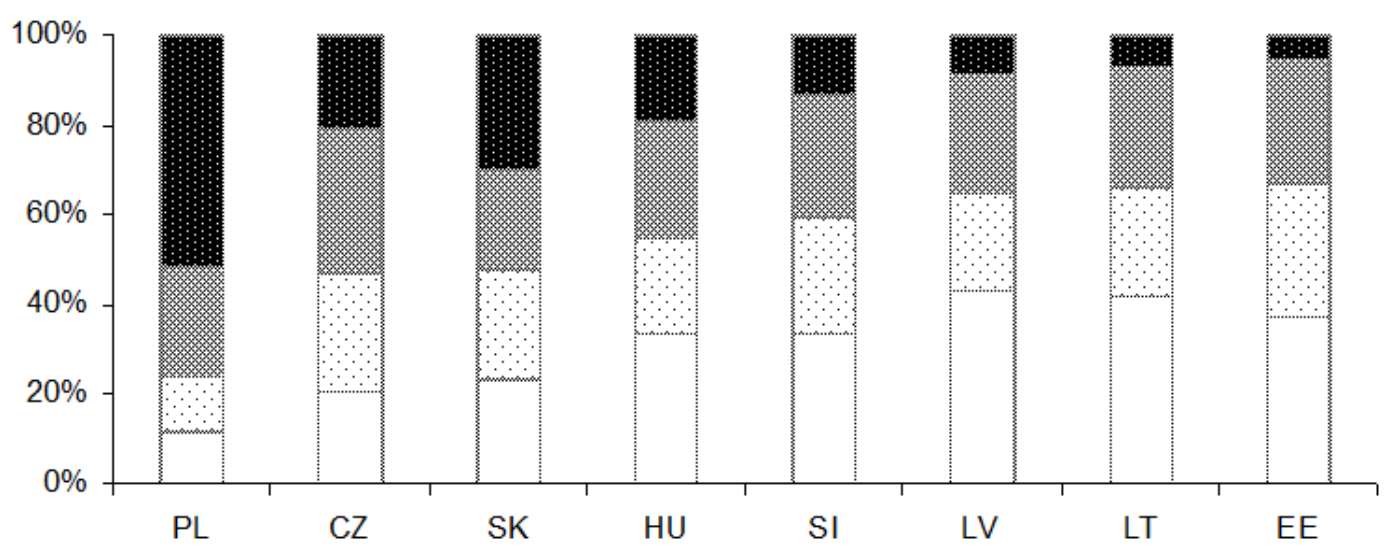

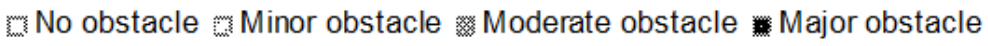

Figure 4: Cost of financing by countries

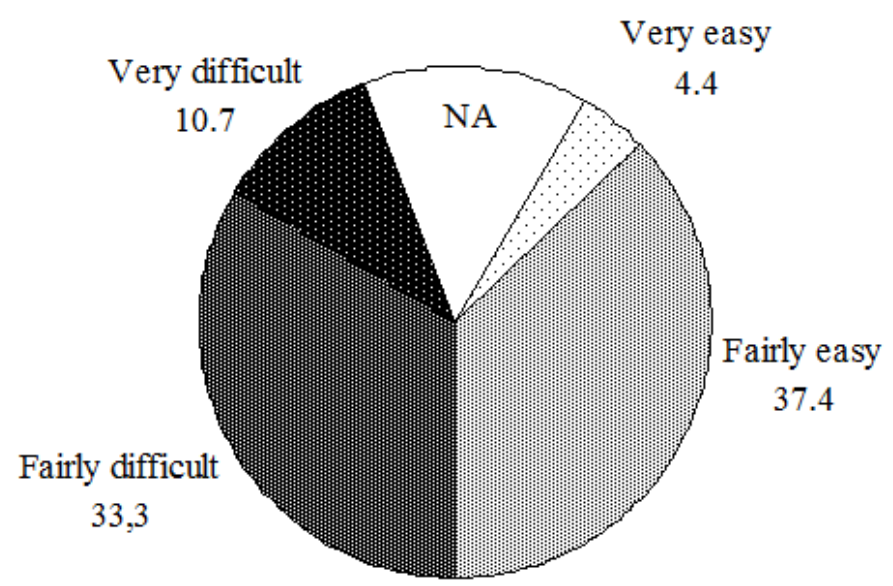

Figure 5: Access to finance through banks in new EU-10 countries

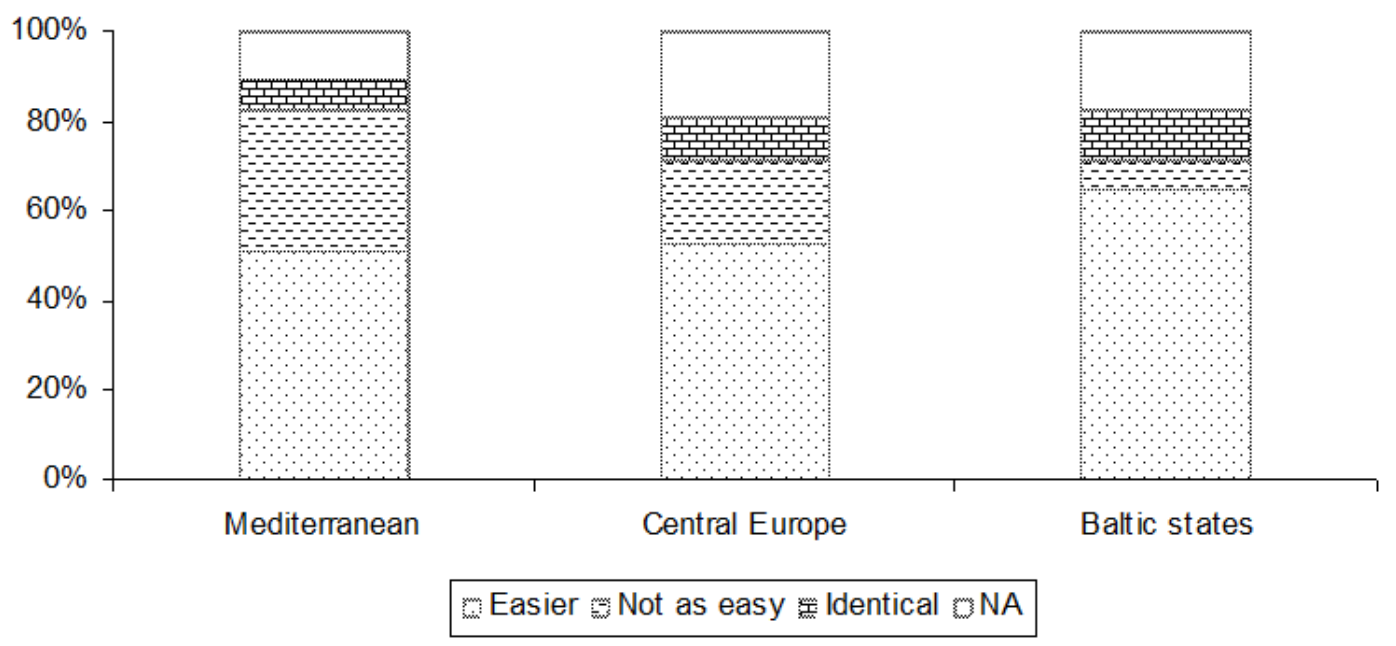

Figure 6: Changes in access to finance through banks 

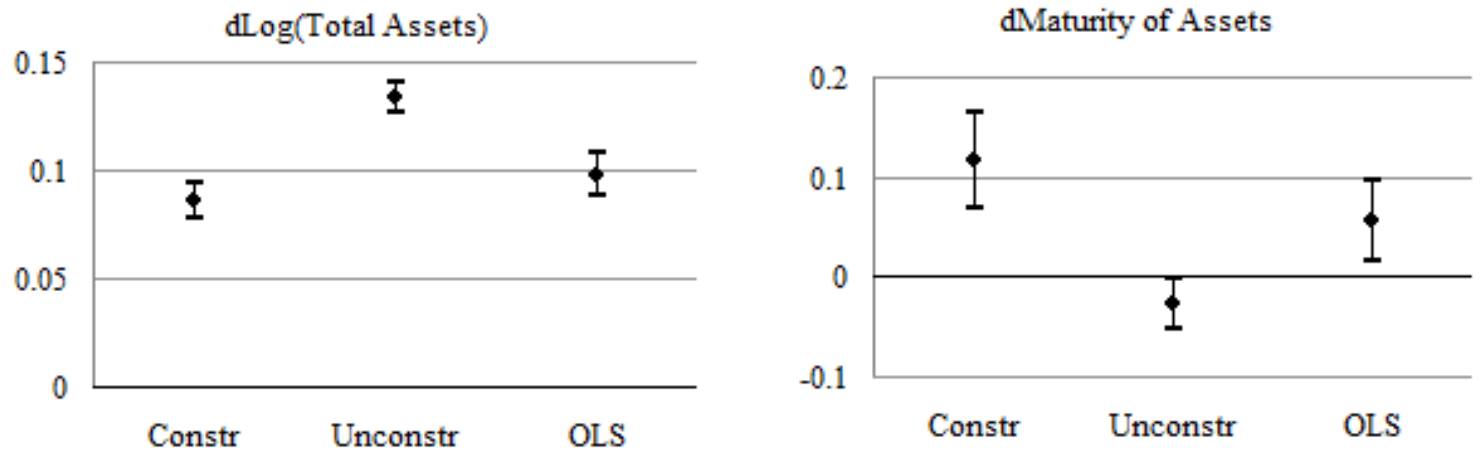

dLog(Age)

dTangibility
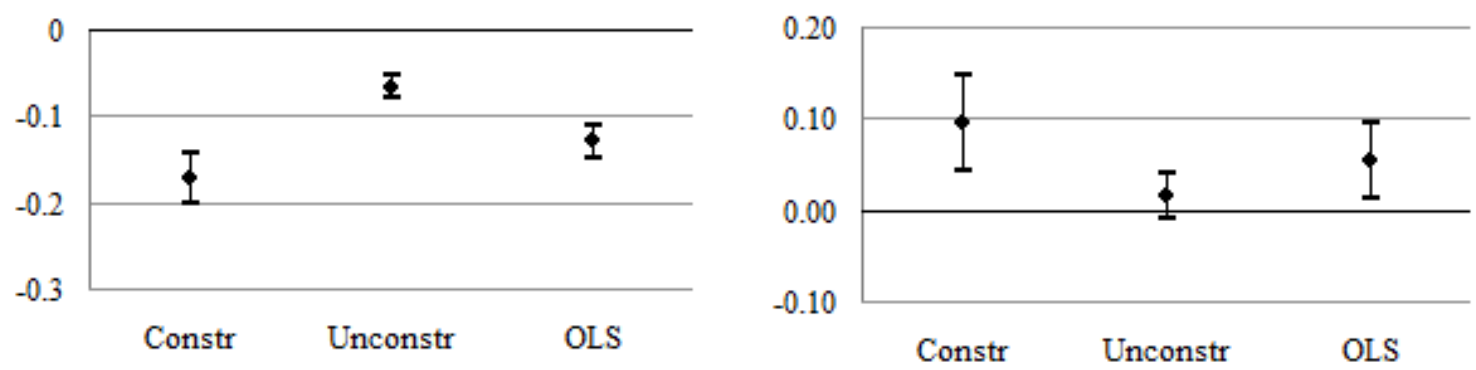

dProfitability
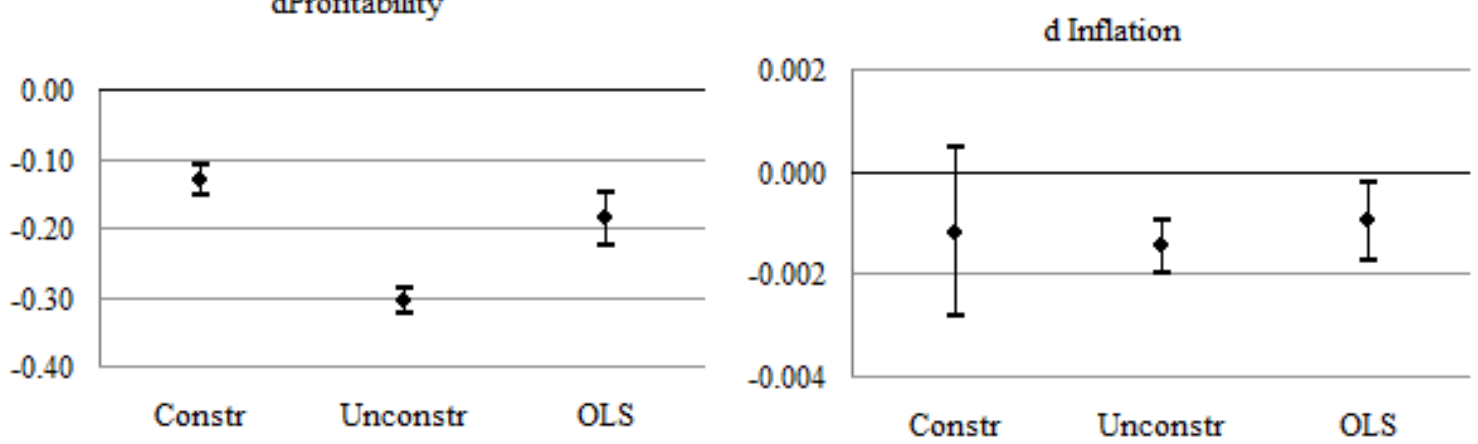

dGDP
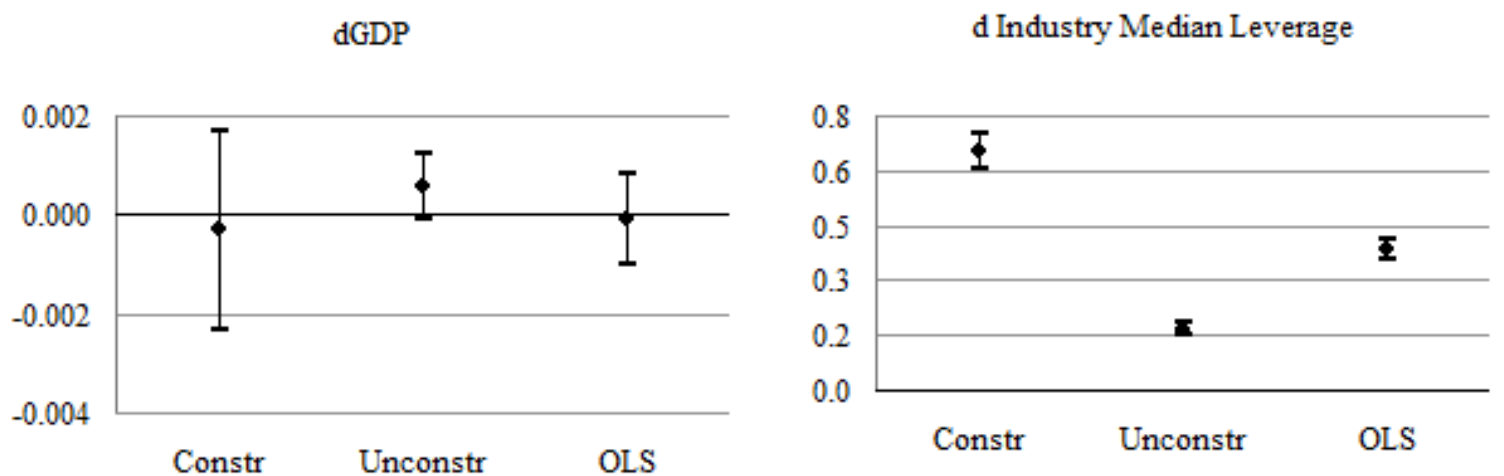

Figure 7: Differences in coefficients 


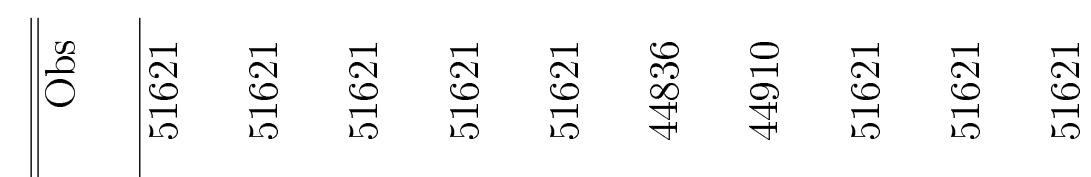

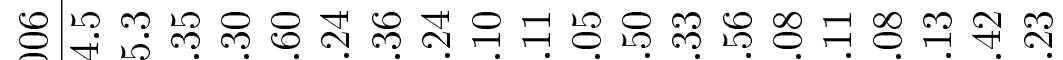

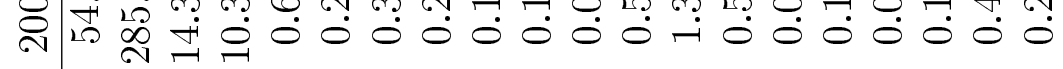

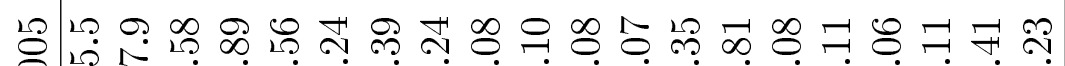

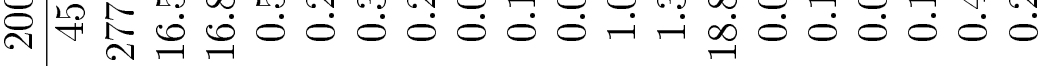

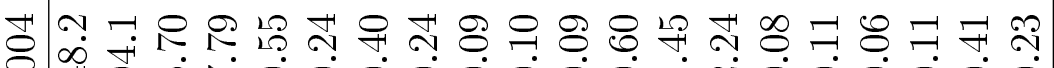
ন

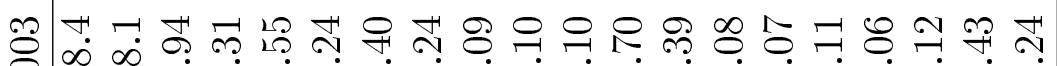
৩ ชิ

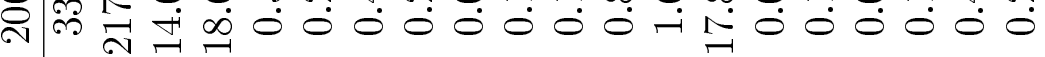
ข 穴

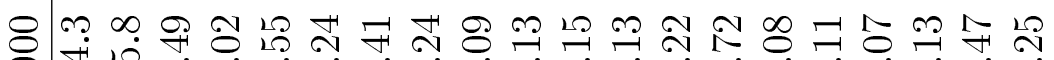
จ

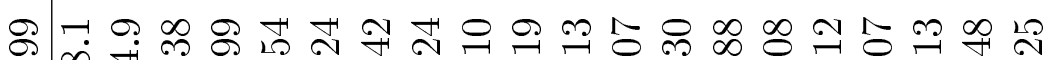

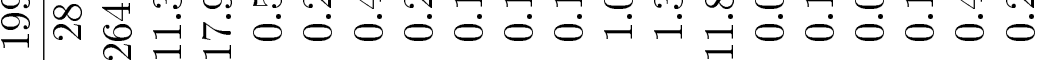

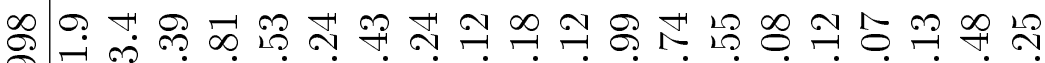

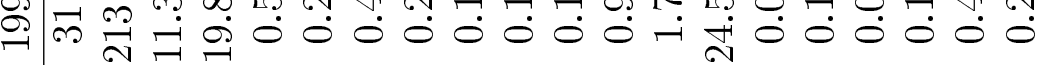

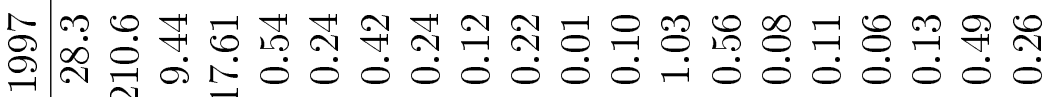
\&:

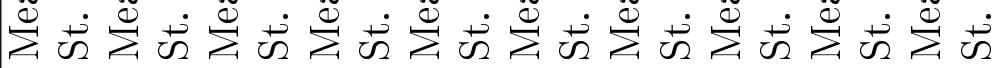

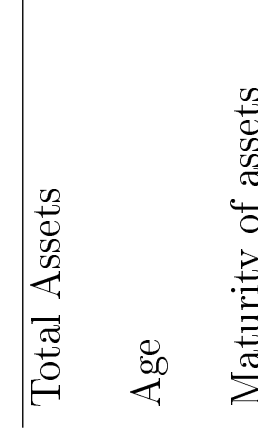

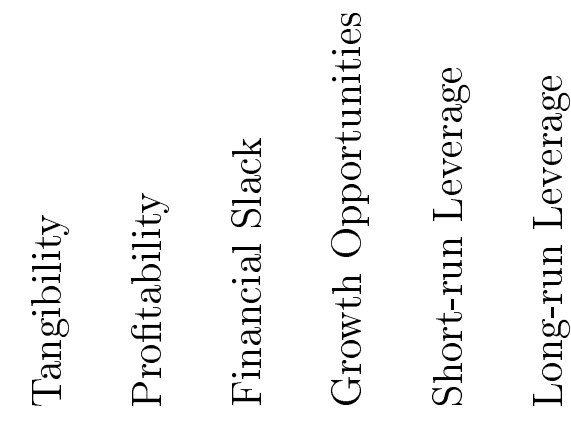




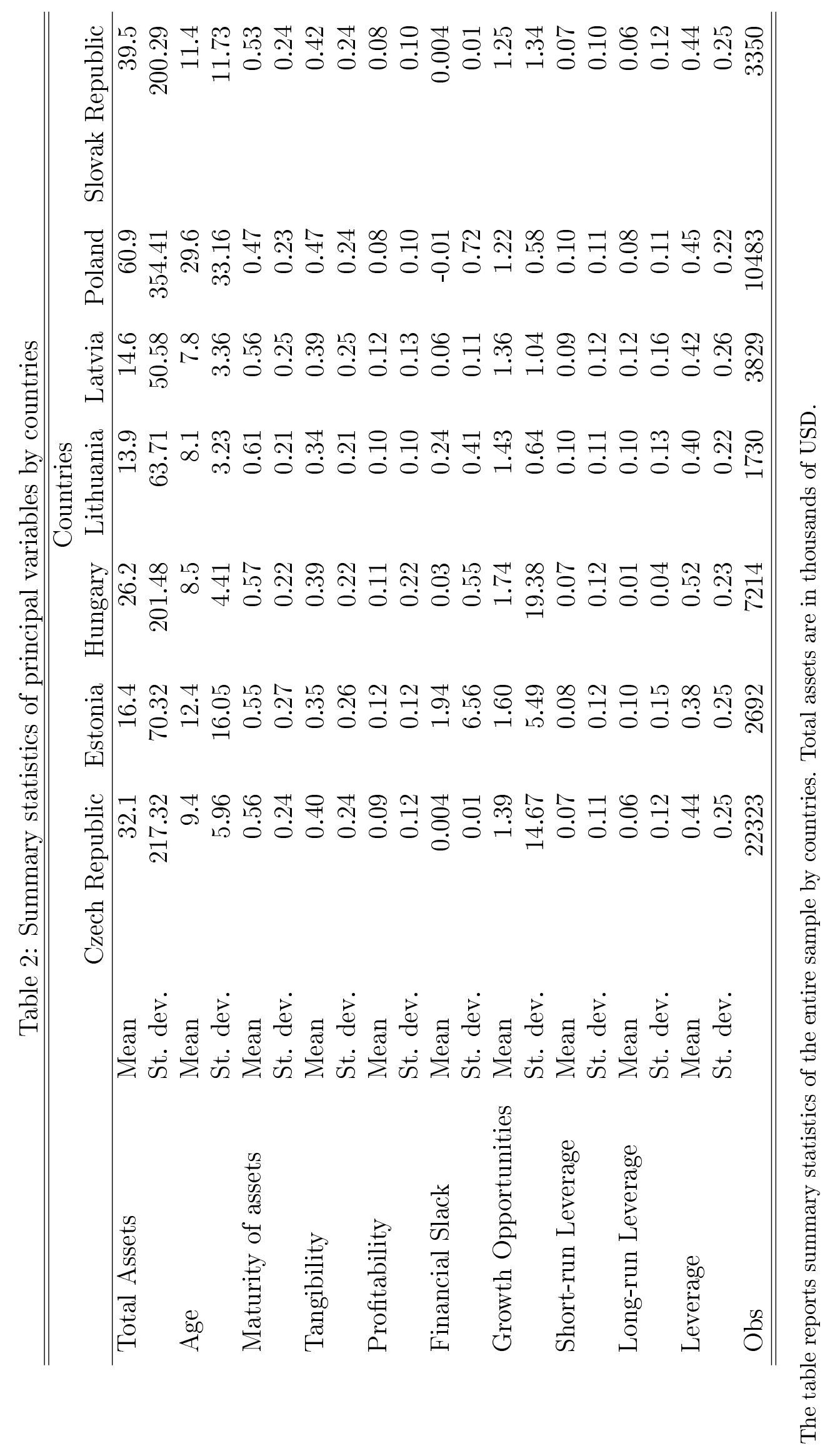


Table 3: Sample Separation Criteria

\begin{tabular}{|c|c|c|}
\hline Criteria & Expected effect & Reference \\
\hline Size & Negative effect & $\begin{array}{l}\text { Hovakimian and Titman (2006) } \\
\text { Myers and Majluf (1984) } \\
\text { Oliner and Rudebusch (1992) } \\
\text { Hobdari, Derek and Mygind (2009) } \\
\text { Almeida and Campello (2007) }\end{array}$ \\
\hline Age & Negative effect & $\begin{array}{l}\text { Hovakimian and Titman (2006) } \\
\text { Hobdari, Derek and Mygind (2009) } \\
\text { Almeida and Campello (2007) }\end{array}$ \\
\hline Leverage & Positive effect & $\begin{array}{l}\text { Hovakimian and Titman (2006) } \\
\text { Hobdari, Derek and Mygind (2009) } \\
\text { Almeida and Campello (2007) } \\
\text { Myers (1977) } \\
\text { Jensen and Meckling (1976) }\end{array}$ \\
\hline Financial Slack & $\begin{array}{l}\text { Positive/ } \\
\text { Negative effect }\end{array}$ & $\begin{array}{l}\text { Kaplan and Zingales (1997) } \\
\text { Fazzari, Hubbard and Petersen (1988) } \\
\text { Hovakimian and Titman (2006) } \\
\text { Almeida and Campello (2007) }\end{array}$ \\
\hline Growth Opportunities & Positive effect & $\begin{array}{l}\text { Almeida and Campello (2007) } \\
\text { Hovakimian and Titman (2006) }\end{array}$ \\
\hline Tangibility & Negative effect & Almeida and Campello (2007) \\
\hline Soft budget constraints & Negative effect & Hobdari, Derek and Mygind (2009) \\
\hline Quoted & Negative effect & Brav (2009) \\
\hline Firm-specific interest rate ${ }^{a}$ & Positive effect & Haas and Peeters (2006) \\
\hline Majority foreign ownership ${ }^{b}$ & Negative effect & \\
\hline
\end{tabular}

a Although a firm-specific interest rate is a valid determinant of the financial constraints because it proxies for the external finance premium firms face, it is not included in the final specification of the model. The reasoning under this decision is twofold. First, the inclusion of firm-specific interest rate calculated as [100*total interest paid/(long-term debt plus loans)] does not substantially affect the results (available upon request). Second, the inclusion of the firm-specific interest rate in the model significantly reduces the number of observations in the sample because the interest paid is missing for $2 / 3$ of firms in the sample.

$b$ I used the indicator of foreign majority ownership to control for the firms' opportunities to obtain financing through the channels different from debt or equity issuing. The obtained results are qualitatively unaffected therefore are not reported, but available upon request. 
Table 4: Switching Regression Model

\begin{tabular}{|c|c|c|c|c|c|}
\hline \multicolumn{6}{|c|}{ Panel A. Leverage regressions } \\
\hline & \multicolumn{2}{|c|}{ Constrained } & \multicolumn{2}{|c|}{ Unconstrained } & Differences in coef- \\
\hline Log(Total Assets) & $0.09^{* * *}$ & $(0.004)$ & $0.13^{* * *}$ & $(0.003)$ & 0.000 \\
\hline Log(Age) & $-0.17^{* * *}$ & $(0.014)$ & $-0.07^{* * *}$ & $(0.006)$ & 0.000 \\
\hline Maturity of Assets & $0.12^{* * *}$ & $(0.024)$ & $-0.03^{* *}$ & $(0.012)$ & 0.000 \\
\hline Tangibility & $0.10^{* * *}$ & $(0.026)$ & 0.02 & $(0.013)$ & 0.010 \\
\hline Profitability & $-0.13^{* * *}$ & $(0.011)$ & $-0.31^{* * *}$ & $(0.009)$ & 0.000 \\
\hline GDP & -0.0003 & $(0.001)$ & $0.001^{*}$ & $(0.0004)$ & 0.424 \\
\hline Expected inflation & -0.001 & $(0.001)$ & $-0.002^{* * *}$ & $(0.0003)$ & 0.748 \\
\hline Industry median & $0.66^{* * *}$ & $(0.024)$ & $0.17^{* * *}$ & $(0.009)$ & 0.000 \\
\hline \multicolumn{6}{|c|}{ Panel B. The Selection equation } \\
\hline const & & $2.01^{* * *}$ & & $(1.157)$ & \\
\hline Log(Total Assets) & & $-0.17^{* * *}$ & & $(0.023)$ & \\
\hline Log(Age) & & $-0.22^{* * *}$ & & $(0.054)$ & \\
\hline Tangibility & & $-2.38^{* * *}$ & & $(0.172)$ & \\
\hline $\mathrm{SBC}$ & & $0.46^{* * *}$ & & $(0.137)$ & \\
\hline Short-run Leverage & & $-3.04^{* * *}$ & & $(0.608)$ & \\
\hline Long-run Leverage & & -0.17 & & $(0.610)$ & \\
\hline Financial Slack & & $-0.05^{*}$ & & $(0.044)$ & \\
\hline Growth Opportunities & & $0.27^{* * *}$ & & $(0.070)$ & \\
\hline Quoted & & 0.04 & & $(0.189)$ & \\
\hline Obs & & 37591 & & & \\
\hline
\end{tabular}

Note: The table reports parameter estimates from endogenous switching regression model with unknown sample separation. The book leverage regressions are estimated in first differences and include year dummies to control for fixed-year effects. Leverage is defined as debt over debt plus equity, where debt is equal total liabilities minus trade credit. Tangibility is defined as tangible assets to total assets. Profitability is equal to profit over total assets. Maturity of assets is current assets over total assets. Median industry leverage is measured as the median leverage of the group defined by the industry code (NACE double digit) and by year. The selection equation is estimated by probit model, where the dependent variable is an indicator taking value of one for firms classified as financially constrained and zero for firms classified as financially unconstrained. All independent variables are one-year lagged. Firm is assumed to face soft budget constraints if it is not profitable, but receives positive net bank financing. Short-run leverage and long-run leverage are defined respectively as short-term debt and long-term debt over total assets. Financial slack is calculated as cash over 1-year lagged total assets. Growth opportunities are proxied by the percentage change in total assets from the previous to the current year. Quoted is a dummy variable for listed firms.

The p-values for the coefficient differences in two regimes are based on the Wald test. ${ }^{* * *},{ }^{* *}$, and ${ }^{*}$ denote statistical significance at the $1 \%, 5 \%$, and $10 \%$ level correspondingly. 
Table 5: Pooled OLS vs. Switching regression model.

\begin{tabular}{|c|c|c|c|c|c|c|}
\hline \multirow{3}{*}{ Log(Total Assets) } & \multirow{2}{*}{\multicolumn{2}{|c|}{ Pooled OLS }} & \multicolumn{4}{|c|}{ Switching regression } \\
\hline & & & \multicolumn{2}{|c|}{ Constrained } & \multicolumn{2}{|c|}{ Unconstrained } \\
\hline & $0.10^{* * *}$ & $(0.005)$ & $0.09^{* * *}$ & $(0.004)$ & $0.13^{* * *}$ & $(0.003)$ \\
\hline Log(Age) & $-0.13^{* * *}$ & $(0.009)$ & $-0.17^{* * *}$ & $(0.014)$ & $-0.07^{* * *}$ & $(0.006)$ \\
\hline Maturity of Assets & $0.06^{* * *}$ & $(0.020)$ & $0.12^{* * *}$ & $(0.024)$ & $-0.03^{* *}$ & $(0.012)$ \\
\hline Tangibility & $0.06^{* * *}$ & $(0.021)$ & $0.10^{* * *}$ & $(0.026)$ & 0.02 & $(0.013)$ \\
\hline Profitability & $-0.19^{* * *}$ & $(0.019)$ & $-0.13^{* * *}$ & $(0.011)$ & $-0.31^{* * *}$ & $(0.009)$ \\
\hline GDP & -0.0001 & $(0.0005)$ & -0.0003 & $(0.001)$ & $0.001^{*}$ & $(0.0004)$ \\
\hline Expected inflation & $-0.001^{* *}$ & $(0.0004)$ & -0.001 & $(0.001)$ & $-0.002^{* * *}$ & $(0.0003)$ \\
\hline Industry median & $0.38^{* * *}$ & $(0.014)$ & $0.66^{* * *}$ & $(0.024)$ & $0.17^{* * *}$ & $(0.009)$ \\
\hline
\end{tabular}

Note: The table reports parameter estimates from pooled OLS model and endogenous switching regression model with unknown sample separation. The book leverage regressions are estimated in first differences and include year dummies to control for fixed-year effects. Leverage is defined as debt over debt plus equity, where debt is equal total liabilities minus trade credit. Tangibility is defined as tangible assets to total assets. Profitability is equal to profit over total assets. Maturity of assets is current assets over total assets. Median industry leverage is measured as the median leverage of the group defined by the industry code (NACE double digit) and by year.

${ }^{* * *},{ }^{* *}$, and ${ }^{*}$ denote statistical significance at the $1 \%, 5 \%$, and $10 \%$ level correspondingly. 
Table 6: Pooled OLS regression with a priori artificial sample separation.

\begin{tabular}{|c|c|c|c|c|}
\hline Leverage & \multicolumn{2}{|c|}{$\begin{array}{l}\text { Constrained } \\
\text { Panel A }\end{array}$} & \multicolumn{2}{|c|}{ Unconstrained } \\
\hline Log(Total Assets) & $0.10^{* * *}$ & $(0.014)$ & $0.10^{* * *}$ & $(0.019)$ \\
\hline Log(Age) & $-0.09^{* *}$ & $(0.039)$ & $-0.06^{*}$ & $(0.035)$ \\
\hline Maturity of Assets & 0.14 & $(0.084)$ & 0.02 & $(0.053)$ \\
\hline Tangibility & $0.23^{* *}$ & $(0.099)$ & 0.05 & $(0.055)$ \\
\hline Profitability & $-0.38^{* * *}$ & $(0.060)$ & $-0.08^{* *}$ & $(0.029)$ \\
\hline GDP & $0.0075^{* *}$ & $(0.003)$ & 0.001 & $(0.001)$ \\
\hline Expected inflation & -0.0005 & $(0.002)$ & -0.002 & $(0.003)$ \\
\hline Industry median & $0.27^{* * *}$ & $(0.062)$ & $0.36^{* * *}$ & $(0.039)$ \\
\hline Obs & 2403 & & 2269 & \\
\hline \multicolumn{5}{|c|}{ Panel B } \\
\hline Log(Total Assets) & $0.09^{* * *}$ & $(0.014)$ & $0.15^{* * *}$ & $(0.019)$ \\
\hline Log(Age) & $-0.08^{* *}$ & $(0.030)$ & $-0.133^{* * *}$ & $(0.030)$ \\
\hline Maturity of Assets & 0.06 & $(0.042)$ & -0.10 & $(0.072)$ \\
\hline Tangibility & 0.05 & $(0.060)$ & 0.03 & $(0.063)$ \\
\hline Profitability & $-0.17^{* *}$ & $(0.070)$ & $-0.07^{* *}$ & $(0.033)$ \\
\hline GDP & 0.00161 & $(0.002)$ & -0.001 & $(0.001)$ \\
\hline Expected inflation & -0.00235 & $(0.002)$ & 0.000 & $(0.001)$ \\
\hline Industry median & $0.47^{* * *}$ & $(0.055)$ & $0.28^{* * *}$ & $(0.042)$ \\
\hline Obs & 2837 & & 2511 & \\
\hline
\end{tabular}

Note: The table reports parameter estimates from pooled OLS model. Firms are artificially separated into constrained and unconstrained. The book leverage regressions are estimated in first differences and include year dummies to control for fixed-year effects. Leverage is defined as debt over debt plus equity, where debt is equal total liabilities minus trade credit. Tangibility is defined as tangible assets to total assets. Profitability is equal to profit over total assets. Maturity of assets is current assets over total assets. Median industry leverage is measured as the median leverage of the group defined by the industry code (NACE double digit) and by year.

${ }^{* * *},{ }^{* *}$, and ${ }^{*}$ denote statistical significance at the $1 \%, 5 \%$, and $10 \%$ level correspondingly. 
Table 7: Financial Constraints and Adjustment Speed.

\begin{tabular}{|c|c|c|c|c|}
\hline Leverage & \multicolumn{2}{|c|}{ Unconstrained } & \multicolumn{2}{|c|}{ Constrained } \\
\hline Lag of Leverage & $0.44^{* * *}$ & $(0.083)$ & $0.83^{* * *}$ & $(0.041)$ \\
\hline Log(Total Assets) & -0.01 & $(0.050)$ & -0.01 & $(0.031)$ \\
\hline Log(Age) & 0.06 & $(0.045)$ & 0.04 & $(0.019)$ \\
\hline Maturity of Assets & -0.11 & $(0.249)$ & -0.28 & $(0.366)$ \\
\hline Tangibility & 0.02 & $(0.328)$ & -0.12 & $(0.337)$ \\
\hline Profitability & -0.02 & $(0.042)$ & 0.08 & $(0.107)$ \\
\hline GDP & -0.002 & $(0.006)$ & -0.001 & $(0.003)$ \\
\hline Expected inflation & 0.002 & $(0.003)$ & 0.001 & $(0.001)$ \\
\hline Industry median leverage & $0.34^{* * *}$ & $(0.120)$ & $0.18^{* * *}$ & $(0.057)$ \\
\hline Wald test & \multicolumn{2}{|c|}{$125.52^{* * *}$} & \multicolumn{2}{|c|}{$794.97^{* * *}$} \\
\hline No 2nd order serial correlation & \multicolumn{2}{|c|}{0.41} & \multicolumn{2}{|c|}{0.45} \\
\hline Obs & \multirow{2}{*}{\multicolumn{2}{|c|}{$\begin{array}{c}2985 \\
817\end{array}$}} & \multicolumn{2}{|c|}{9547} \\
\hline Firms & & & \multirow{2}{*}{\multicolumn{2}{|c|}{$\frac{2108}{17 \%}$}} \\
\hline Adjustment Speed & \multicolumn{2}{|c|}{$56 \%$} & & \\
\hline
\end{tabular}

Note: The table reports parameter estimates from a partial adjustment model with firm fixed effects as suggested by Flannery and Rangan (2006). Firms are assigned to constrained and unconstrained categories using calculated probabilities of the firm to be in either regime from the estimated switching model. The model is estimated in first differences using GMM, the levels of all independent variables at the second lag are used as instruments. The book leverage regressions are estimated in first differences and include year dummies to control for fixed-year effects. Leverage is defined as debt over debt plus equity, where debt is equal total liabilities minus trade credit. Tangibility is defined as tangible assets to total assets. Profitability is equal to profit over total assets. Maturity of assets is current assets over total assets. Median industry leverage is measured as the median leverage of the group defined by the industry code (NACE double digit) and by year.

${ }^{* * *},{ }^{* *}$, and ${ }^{*}$ denote statistical significance at the $1 \%, 5 \%$, and $10 \%$ level correspondingly. 


\section{Working Paper Series}

ISSN 1211-3298

Registration No. (Ministry of Culture): E 19443

Individual researchers, as well as the on-line and printed versions of the CERGE-EI Working Papers (including their dissemination) were supported from the European Structural Fund (within the Operational Programme Prague Adaptability), the budget of the City of Prague, the Czech Republic's state budget and the following institutional grants:

- Center of Advanced Political Economy Research [Centrum pro pokročilá politickoekonomická studia], No. LC542, (2005-2010);

- Economic Aspects of EU and EMU Entry [Ekonomické aspekty vstupu do Evropské unie a Evropské měnové unie], No. AVOZ70850503, (2005-2010);

- Economic Impact of European Integration on the Czech Republic [Ekonomické dopady evropské integrace na ČR], No. MSM0021620846, (2005-2011);

Specific research support and/or other grants the researchers/publications benefited from are acknowledged at the beginning of the Paper.

(c) Anastasiya Shamshur, 2010

All rights reserved. No part of this publication may be reproduced, stored in a retrieval system or transmitted in any form or by any means, electronic, mechanical or photocopying, recording, or otherwise without the prior permission of the publisher.

Published by

Charles University in Prague, Center for Economic Research and Graduate Education (CERGE) and

Economics Institute ASCR, v. v. i. (EI)

CERGE-El, Politických vězňů 7, 11121 Prague 1, tel.: +420 224005 153, Czech Republic.

Printed by CERGE-EI, Prague

Subscription: CERGE-EI homepage: http://www.cerge-ei.cz

Phone: + 420224005153

Email: office@cerge-ei.cz

Web: http://www.cerge-ei.cz

Editor: Michal Kejak

Editorial board: Jan Kmenta, Randall Filer, Petr Zemčík

The paper is available online at http://www.cerge-ei.cz/publications/working_papers/.

ISBN 978-80-7343-230-0 (Univerzita Karlova. Centrum pro ekonomický výzkum a doktorské studium)

ISBN 978-80-7344-220-0 (Národohospodářský ústav AV ČR, v. v. i.) 
CERGE-EI

P.O.BOX 882

Politických vězňů 7

11121 Praha 1

Czech Republic http://www.cerge-ei.cz 